\title{
A compaixão de Jesus com a mãe viúva de Naim (Lc 7,1 1-17): o emprego do verbo splangxizomai na perícope e no Evangelho de Lucas
}

\author{
Orientador: Isidoro Mazzarolo
}

Doutorando: Ildo Perondi

Área de Concentração: Teologia Bíblica

Linha de Pesquisa: Análise e Interpretação de Textos do Antigo e Novo Testamento

Esta pesquisa é um estudo e análise do relato de Lc 7,11-17, mais conhecido como a ressurreição do filho da viúva de Naim, procurando entender o sentimento de compaixão de Jesus ao ver a mãe viúva que estava levando seu único filho para ser sepultado. Este sentimento foi definido por Lucas com o emprego do verbo splangxizomai (ser movido de compaixão). Foram estudados os critérios para o emprego deste verbo na perícope e nas demais ocorrências no Evangelho de Lucas. Para a análise e interpretação de Lc 7,11-17 foram utilizados elementos essenciais do método histórico-crítico. Portanto, foi feita a análise diacrônica do texto e, ao analisar a forma com que Lucas emprega o verbo splangxizomai em seu Evangelho, a análise foi sincrônica, considerando o texto em sua forma final e revelando o caminho de provocação do leitor que é desenhado pela estrutura de Lc 7,11-17 ligada ao Evangelho como um todo. Nossa pesquisa valorizou os estudos diacrôni-cos fazendo a interface com os estudos sincrônicos e análises intertextuais. Os resultados alcançados foram uma melhor compreensão do relato, evidenciando que o fato de Jesus ter sido movido de compaixão diante da mãe viúva resultou na solução do problema. Com a sua palavra Jesus reanimou o jovem morto e o entregou à sua mãe e as multidões reconheceram o episódio como uma visita de Deus ao seu povo. Demonstramos que ao empregar o verbo splangxizomai Lucas o fez conscientemente e coerentemente utilizando critérios literários e com 
seu próprio estilo narrativo, onde o mesmo funciona como turning point, isto é, como ponto de mutação e serve de modelo para o uso do verbo nas demais passagens do Evangelho (Lc 10,33 e 15,20).

Palavras-chave: Jesus. Compaixão. Profeta. 